\title{
Recent Developments in Photovoltaics
}

\author{
J. Stone \\ E. Witt \\ R. McConnell \\ T. Flaim \\ T. Surek \\ D. Ritchie
}

May 1984

Presented at the

17th IEEE PV Specialists Conference Orlando, Florida

1-5 May 1984

Prepared under Task No. 3411.10

FTP No. 460

Solar Energy Research Institute

A Division of Midwest Research Institute

1617 Cole Boulevard

Golden, Colorado 80401

Prepared for the

U.S. Department of Energy

Contract No. DE-AC02-83CH10093 
Printed in the United States of America Available from:

National Technical Information Service

U.S. Department of Commerce

5285 Port Royal Road

Springfield, VA 22161

Price:

Microfiche A01

Printed Copy A02

\section{NOTICE}

This report was prepared as an account of work sponsored by the United States Government. Neither the United States nor the United States Department of Energy, nor any of their employees, nor any of their contractors, subcontractors, or their employees, makes any warranty, express or implied, or assumes any legal liability or responsibility for the accuracy, completeness or usefulness of any information, apparatus, product or process disclosed, or represents that its use would not infringe privately owned rights. 


\title{
RECENT DEVELOPMENTS IN PHOTOVOLTAICS
}

\author{
J. Stone, E. Witt, R. McConnell, T. Flaim, \\ T. Surek, and D. Ritchie
}

Solar Energy Research Institute Golden, Colorado 80401

\section{ABSTRACT}

In this paper we describe the long-term (late 1990s) cost and efficiency goals of the recently issued National Photovoltaics Program Five-Year Research Plan, technical goals which are besed on a constant dollar electricity cost target of 6.5 cents/kWh. We next discuss an assessment using material requirements for estimating the potential of different PV technologies to meet these goals. This assessment suggests that thin-film PV technologies, especially amorphous silicon, have much potential for achieving the long-term goals. Finally, we describe the recent achievements and near-term thrusts of the research efforts conducted by SERI.

\section{INTRODUCTION}

The Department of Energy's recent Five-Year Research Plan (1984-1988) for the National Photovoltaics Program proposes ambitious long-term goals for the cost and performance of PV modules. The Plan also proposes a federal/industry partnership in which the final achievement and demonstration of these long-term goals, especially the technical cost goals, are the responsibility of industry. The federal government assists by sponsoring the high-risk, potentially high-payoff research and development that industry is unlikely to pursue because of the costs and risks involved. This sponsored work is directed primarily toward technical efficiency and durability goals.

SERI is one of three federally designated research centers (the other two being the Jet Propulsion Laboratory in Pasadena, California, and Sandia National Laboratories in Albuquerque, New Mexico) working to fulfill the objectives of the Five-Year Research Plan. SERI's specific activities involve management of subcontracted $R \& D$, development of state-of-the-art measurement and device capabilities, advanced and basic research, and transfer of R\&D results to industry. PV research activities are conducted with promising materials, including amorphous silicon; polycrystalline thin films, including cadmium sulfide/copper binary and ternary material combinations; and gallium arsenide and other III-V high-efficiency materials. Both basic and advanced research are conducted in high-efficiency crystalline silicon solar cells, and in photoelectrochemical cells and other innovative concepts. The objective of innovative concepts research is to identify new materials, device configurations, and ideas and to conduct preliminary research and development in the most promising of these new areas.

\section{RESBARCH GOAW}

\section{Five-Year Research Plan}

An important PV development in 1983 was the completion of a new Five-Year Research Plan (1984-1988) for the National Photovoltaics Program funded by the U.S. Department of Energy (1). The plan's primary research emphasis is the development of promising new approaches to photovoltaic cells such as thin-film and multijunction concepts. This emphasis is consistent with the program's purpose of sponsoring high-risk, potentially high-payoff research and development in photovoltaic energy technology which will result in a technology base from which private enterprise can choose options for further development and competitive application in U.S. electrical energy markets. In order to obtain a high payoff, 6.5 cents per kilowatt-hour (constant 1982 dollars) is targeted as the cost of electricity to be produced by PV systems in the late 1990s. (This corresponds to a current dollar energy cost of 15 cents per kilowatt-hour, the number in the Five-Year Research Plan.) This planning target is competitive with projected electricity costs of conventional alternatives in the 1990 s and would establish photovoltaics as a viable energy supply option for U.S. electric utilities. From this electricity cost target, the Five-Year Research Plan derives ambitious long-term goals for the cost and performance of PV modules. The long-term goals, listed in Table 1, specify module cost and module efficiency combinations necessary for future PV systems producing 6.5 cents per kilowatt-hour electricity. The technical and economic assumptions leading to these goals are besed on earlier Electric Power Research Institute $(2,3)$ and DOE analyses and are described in the Five-Year Research Plan (1).

An important attribute of the plan is the perpetuation of a partnership between industry and the federal government. The federal role is to sponsor research activities having the potential for achieving long-term benefits to society in areas that industry is unlikely to pursue alone because of the costs and risks involved. Characteristic of this partnership is cost-shared research efforts requiring long-term commitments by both industry and the government. Final achievement and demonstration of the long-term goals, especially the technical cost 
Table 1. Federal/mowry Long-Term (Late 1990s) Technical Goals (1982 dollars)

\begin{tabular}{lcc}
\hline & $\begin{array}{c}\text { Flat-Plate } \\
\text { Systems }\end{array}$ & $\begin{array}{c}\text { Concentrator } \\
\text { Systems }\end{array}$ \\
\hline Module Efficiency & $13 \%-17 \%$ & $23 \%-29 \%$ \\
Module Cost & $\$ 40-\$ 75 / \mathrm{m}^{2}$ & $\$ 90-\$ 160 / \mathrm{m}^{2}$ \\
Balance-of-System Costs & $\$ 50 / \mathrm{m}^{2}$ & $\$ 100 / \mathrm{m}^{2}$ \\
-Area-related & $\$ 150 / \mathrm{kW}$ & $\$ 150 / \mathrm{kW}$ \\
-Power-related & 30 years & 30 years \\
\hline
\end{tabular}

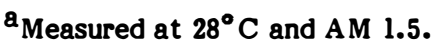

goals, however, are industry's responsibility. To quote from the Five-Year Research Plan (1):

Ultimately, the final achievement and demonstration of these goals are the responsibility of industry. The federal government will essist by developing subcomponent and subprocess techniques which will result in the efficiency and durability goals and by providing analytical validation of the viability of the technical cost goals. Further development and scale-up by industry will be required to achieve the technical cost goals (i.e., $\$ / \mathrm{m}^{2}$ ).

\section{Cost Competitiveness}

The allowable cost for PV systems is based on the assumption that the cost of PV-derived electricity must be comparable to that available from other new options from which a utility would choose in order to meet demand and minimize costs. These energy cost comparisons may be carried out in either levelized current dollars, as in the Five-Year Research Plan, or in levelized constant dollars. The fundamental difference between current dollars and constant dollars is that current dollars include general inflation (8.5\% in the Five-Year Research Plan analysis) while constant dollars do not. The PV technology goals derived from either analysis are the same as long as the input data are consistent and the results are reported in the same base-year dollars. This paper reports energy costs in 30-year levelized constant dollars.

The allowable cost chosen in the EPRI studies, 6.5 cents per kilowatt-hour, is midway between energy costs from new oil and new coal generation and is comparable to the cost of energy from new coal generating systems operating at capacity factors which can be expected from PV generation (3). Under circumstances where increased demand is the driving force for new generation, detailed site and utility analyses must be performed to determine the contribution PV generation makes to the utility's effective load-carrying capability. Effective load-carrying capability is a measure of the ability of a generating system to provide generating capacity during period of high demand. If the PV system's load-carrying capability is small compared with its rated capacity, then PV energy costs would have to be lower than 6.5 cents per kilowatt-hour in order for PV systems to be economical within utilities facing increased demand.

Another result of EPRI analyses is that the allowable factory selling price will be highest in sales supporting large-scale installations financed by utilities (or thirdparty investors in the case of preferential tax laws) (3). The rate of introducing PV into other applications, such as commercial and residential, will be strongly influenced by the costs involved with product marketing and distribution, stringent consumer and business purchase criteria, and interconnection requirements. These added costs will require significantly lower allowable factory selling prices.

Using the planning target energy cost of 6.5 cents per kilowatt-hour, the PV module cost allowed for the PV system can be calculated from

Annual Energy Cost $=$

$$
\frac{\text { (FCR) (Total Capital Cost) + Levelized O\&M }}{\text { Annual Energy Production }}
$$

where

FCR = Annualized Fixed Charge Rate (0.071 in constant 1982 dollars)

Total Capital $=$ (Indirect Cost Multiplier) $\times$ (PV Module Cost + Balance-of-System Costs)

Annual Energy = Total number of kilowatt hours generProduction ated by the PV system in one year, which is a function of module and BOS efficiency

Levelized = Annual maintenance plus normal operO\&M ating costs levelized over a 30-year life.

The indirect cost multiplier accounts for engineering fees, contingency, owner's cost, interest during construction, marketing, and distribution costs. In the Five-Year Research Plan, this equation is solved for PV module cost as a function of annual energy cost using module efficiency as a parameter. Figure 1 shows the analysis results from the Five-Year Research Plan for fixed flat-plate PV systems. Details of the economic and technical parameters are also given in the Plan as is a similar analysis for concentrator systems (1). It is worthwhile to note that the Five-Year Research Plan analysis and an independent analysis conducted by Chevron are consistent although the Chevron planning target is more like 5 cents per kilowatthour (4).

The module cost-efficiency goals in Table 1 are simply the efficiency intercepts to the planning target and corresponding module costs. The dashed curves are the module cost goals from earlier federal program plans (5). Note that meeting a specified module cost per watt can result in PV systems providing a range of electricity costs, depending on the module efficiency. This occurs because of the relatively larger total balance-of-system cost associated with lower efficiency modules.

Although the economic and technical parameters input to this analysis can be varied, there is general agreement that the achievement of the long-term module 


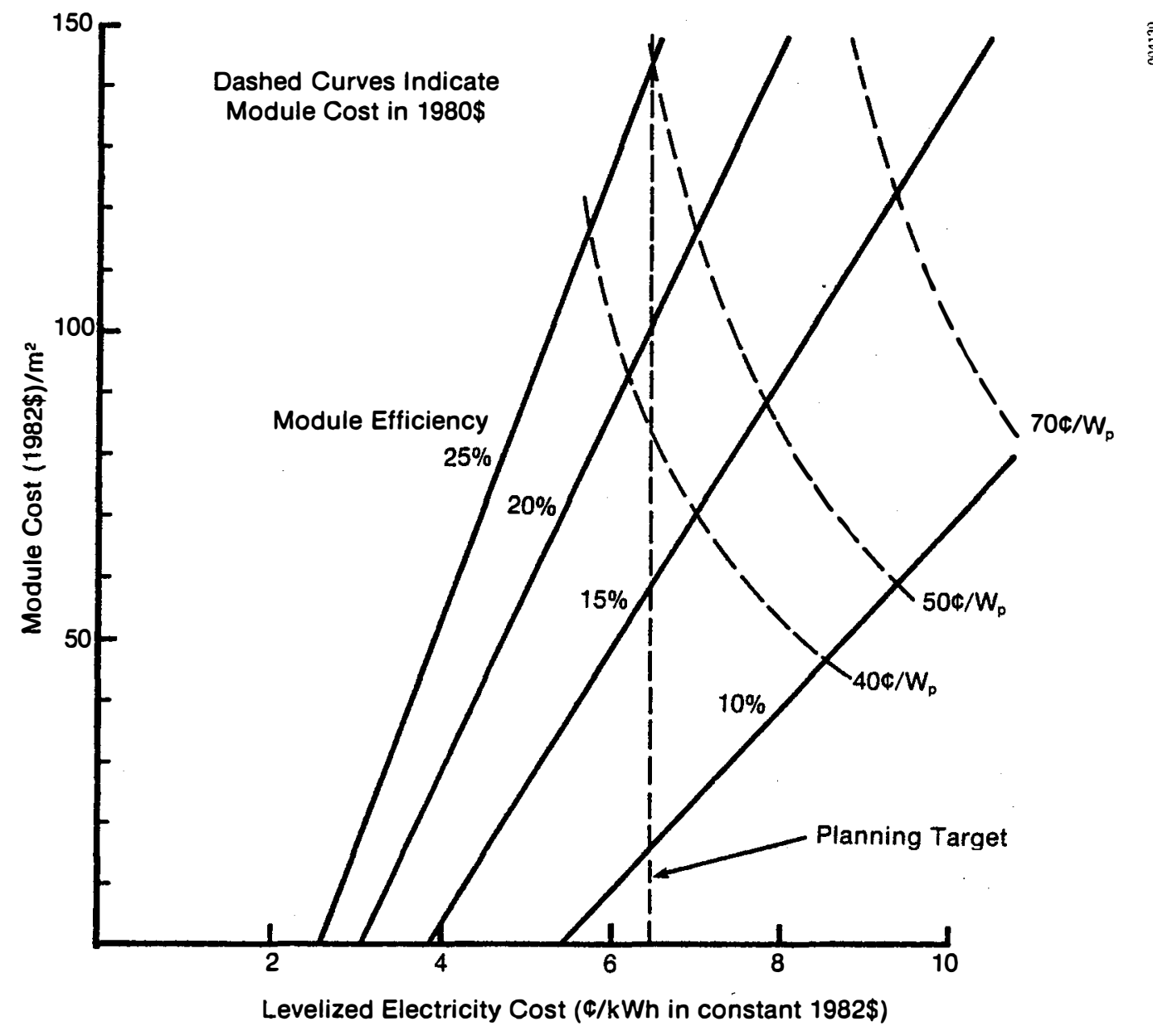

Figure 1. Flat-Plate PV Module Cost as a Funetion of Levelized Eleetrieity Cost in Conştant Dollars for Different Module Efficiencies. Area-related balance-of-system costs assumed at $\$ 50 / \mathrm{m}^{2}$.

cost-efficiency goals in Figure 1 and Table 1 will lead to photovoltaic systems that are viable energy supply options for many U.S. electric utilities.

\section{Technical Attainability}

The purpose of the following discussion is to confirm that the technical goals are viable and to outline the major R\&D challenges for PV technologies. As indicated in Table l, both efficiency and module cost goals must be attained simultaneously in order to meet the planning target of 6.5 cents per kilowatt-hour. Theoretically, the maximum thermodynamic efficiency of an infinite number of active semiconductor layers, each converting a portion of the solar spectrum to electricity, is almost $70 \%$ for flat-plate collectors (1). Practically achievable efficiencies of $30-40 \%$ appear to be feasible with a concentrated research effort on materials and device fabrication (6). In particular, Japanese researchers have proposed a threecell thin-film structure, based on amorphous silicon, with an attainable efficiency estimated to be $24 \%$ (6). Considering the efficiencies of today's thin film cells (about $10 \%$ for small areas) and today's large-area crystalline silicon modules (about $10 \%$ for large areas), researchers and program planners see considerable room for improvement in PV module efficiencies. However, improving module efficiencies is only half of the challenge; the other is to reduce module costs.

Researchers and program planners have used detailed costing analyses to estimate the potential future cost of different photovoltaic technologies. The viewpoint is to take today's PV technology options and project their cost into the future. However, costing analyses of embryonic PV technologies are intrinsically uncertain because it is difficult to estimate the cost of a PV module not yet built using a manufacturing process that cannot be very detailed or specific. More uncertainty results when large-scale production benefits are estimated.

An alternative approach is to look at the major cost drivers of the technologies and attempt to calculate a lower limit for their costs. The viewpoint is to examine PV technology options as if they were fully mature, so that limiting material and fabrication costs can be identified. For example, an early Jet Propulsion Laboratory assessment was made from this latter viewpoint (7). It 
estimated the material requirements (in metric tons per megawatt) and material costs (in dollars per kilogram) for $\mathrm{CuInSe}_{2}$, CdTe, $\mathrm{Cu}_{2} \mathrm{~S}, \mathrm{GaAs}$, and $\mathrm{Si}$ technologies in order to identify potential material availability problems. Such analyses provide some insight into determining which options would have the highest payoff if they were successfully developed as well as help to identify major R\&D challenges.

Assuming that the long-term, mass-production cost of PV modules will ultimately be limited by semiconductor material costs or total module fabrication energy costs, then one can assess the potential for different PV technologies to meet the module cost goals by examining their requirements for materials or fabrication energy. Because the semiconductor in polycrystalline thin-film devices consists of several elements, we shall focus on critical elements that are relatively expensive because of their scarcity or stringent purification requirements. From this point of view, silicon is a critical element, because the purified silicon needed for solar cells is expensive and in great demand by the semiconductor industry, which can tolerate higher material costs $(8,9)$. Table 2 shows the critical element requirements for several PV technologies. The benefits of the thin-film technologies in minimizing the amount of semiconductor materials needed is evident in Table 2.

One assumption for Table 2 is that the thin-film fabrication processes are 50\% efficient in terms of material utilization. Most thin-film fabrication processes can be $50 \%$ efficient or better, but there are significant

Table 2. Material Requirements and Electrical Energy Content for Different PV Technologies

\begin{tabular}{lccc}
\hline & $\begin{array}{c}\text { Critical } \\
\text { Material }\end{array}$ & $\begin{array}{r}\text { Mass/ } \\
\text { Areg } \\
\left(\mathrm{g} / \mathrm{m}^{2}\right)\end{array}$ & $\begin{array}{c}\text { Energy Content/ } \\
\text { Area } \\
\left(\mathrm{kWh} / \mathrm{m}^{2}\right)\end{array}$ \\
\hline $\begin{array}{l}\text { Amorphous Silicon } \\
(2 \mu)\end{array}$ & $\mathrm{Si}$ & 9 & 225 \\
CdS/CuInSe 2 & Cd & 15 & $150^{\mathrm{b}}$ \\
$(2 \mu) /(2 \mu)$ & In & 8 & \\
CdS/CdTe & Se & 11 & \\
$(2 \mu) /(2 \mu)$ & Cd & 26 & $150^{\mathrm{b}}$ \\
& Te & 13 & \\
$\begin{array}{l}\text { GaAs } \\
(2 \mu)\end{array}$ & Ga & 10 & $\cdots$ \\
Silicon Ribbon & As & 11 & \\
$(200 \mu)$ & Si & 580 & 1300 \\
Single-Crystal Si & Si & 1200 & 2500 \\
$(200 \mu)$ & & & \\
\hline
\end{tabular}

$a_{50 \%}$ utilization of critical elements projected for thin films; $80 \%$ utilization projected for silicon ribbon; and single-crystal silicon values are estimated for today's technology.

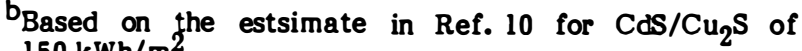
$150 \mathrm{kWh} / \mathrm{m}^{2}$. differences $(8,11)$. For example, RF sputtering tends to be more efficient than thermal evaporation without a material reclaiming process. The glow discharge process for producing amorphous silicon is presently very inefficient without a reclamation system. Ultimately, however, the thin-film fabrication processes for fully developed thin-film technologies will probably have a material utilization much higher than $50 \%$ (11).

There are obvious differences associated with the availability and cost of the critical elements of the different technologies. Several years ago, SERI commissioned Battelle-PNL to study the availability and cost of the critical materials listed in Table $2(11,12,13)$. These studies indicated that such concerns can be important. Current cost quotes are listed in Table 3 along with total critical material costs for each technology listed in Table 2. We see that material costs can be a small fraction of allowed module costs per unit area (see Table 1) for the thin-film technologies. This is not the case for the thick-silicon, silicon ribbon and single-crystal silicon technologies, however. This was evident even in the early JPL assessment of PV technologies (7) and led to a large, federally funded effort to reduce the cost of silicon material. One Five-Year Goal is still to determine the feasibility of processes that can reduce the cost of semiconductor-grade silicon to $\$ 16 / \mathrm{kg}(1)$. However, the thin-film critical materials in Table 3 could also cost less if larger material production facilities existed or if more efficient production processes were to be developed.

Table 2 also includes energy content estimates (10). Energy content is the sum of the equivalent electrical energy needed for all steps from mining and refining ore to constructing and encapsulating a module of solar cells (10). It does not include the content of array structures. Today, energy content represents only one component of the final cost and is no more important than other system costs that need to be reduced. If solar cells are to generate electricity on a large scale, however, then minimum energy content per unit area will be one more indication of the potential of the technology to attain minimum module cost per unit area. Note that the limiting values estimated for CuInSe, and CdTe are based on an energy content estimate of $150 \mathrm{kWh} / \mathrm{m}^{2}$ for $\mathrm{Cu}_{2} \mathrm{~S}$ irrespective of the choice of sputtering, thermal exaporation, or spraying (10). A lower limit of $100 \mathrm{kWh} / \mathrm{m}^{2}$ is the energy content of two glass sheets for thin-film encapsulation assumed necessary for a reasonable lifetime. Again, the significant energy content difference between thin-film and thick-silicon technologies indicates the relative potential of thin-film technologies for attaining, in the long term, minimum total module cost per unit area.

Table 3 provides one lower limit for module cost based on semiconductor material costs. Reference 10, however, includes materials as one component of the total energy content of the completed modules. The Five-Year Research Plan enables us to estimate levelized energy costs over the period 1982-2012 so that the energy content estimates in Table 2 can provide another lower bound for module costs that will be higher than the critical material lower bounds in Table 3. The appropriate factor is the constant dollar energy cost of 6.5 cents per kilowatt-hour which, when multiplied by the energy content estimates in Table 2, gives the energy content module costs in Table 3.

Because of the many approximations needed to identify the limiting module costs in Table 3 , the results are 
Table 3. Material and Energy Content Costs for PV Modules

\begin{tabular}{|c|c|c|c|c|}
\hline & $\begin{array}{l}\text { Critical } \\
\text { Material }\end{array}$ & $\begin{array}{c}\text { Lowest Price } \\
\text { Quote for } \\
\text { about } 99.99 \% \\
\text { Purity } \\
(\$ / \mathrm{kg})\end{array}$ & $\begin{array}{c}\text { Critical } \\
\text { Material } \\
\text { Total } \\
\left(\$ / \mathrm{m}^{2}\right)\end{array}$ & $\begin{array}{c}\text { Energy } \\
\text { Content } \\
\text { Total } \\
\left(\$ / \mathrm{m}^{2}\right)\end{array}$ \\
\hline $\begin{array}{l}\text { Amorphous } \\
\text { Silicon }\end{array}$ & Silane & 150 & 1.35 & 14.63 \\
\hline $\mathrm{CaS} / \mathrm{CuInSe}_{2}$ & $\begin{array}{l}\text { Cd } \\
\text { In } \\
\text { Se }\end{array}$ & $\begin{array}{r}22 \\
160 \\
20\end{array}$ & 1.83 & 9.75 \\
\hline CdS/CdTe & $\begin{array}{l}\text { Cd } \\
\text { Te }\end{array}$ & $\begin{array}{l}22 \\
66\end{array}$ & 1.43 & 9.75 \\
\hline GaAs & $\begin{array}{l}\text { Ga } \\
\text { As }\end{array}$ & $\begin{array}{l}600 \\
150\end{array}$ & 7.65 & - \\
\hline $\begin{array}{l}\text { Silicon } \\
\text { Ribbon }\end{array}$ & Si & 40 & 23.20 & 84.50 \\
\hline $\begin{array}{l}\text { Single- } \\
\text { Crystal } \\
\text { Silicon }\end{array}$ & Si & 40 & 48.00 & 162.50 \\
\hline
\end{tabular}

not as reliable as detailed cost analyses of mature technologies. Even excluding cost, however, the material and energy content requirements in Table 2 provide valuable guidance for the researcher and program planner. The table gives an indication of the relative value of the technologies, assuming that performance goals of efficiency and stability can be achieved.

The mass and energy content requirements of Table 2 suggest that thin-film technologies have a better chance of attaining the flat-plate module cost goals than do the thick-silicon technologies. Even allowing for the relative scarcity of materials, as we have done in Table 3 , thin-film photovoltaic technologies should ultimately have cost advantages related to their low mass and energy content requirements. The thick-silicon technologies will have to have module efficiencies much higher than those of thin-film modules (see Table 1) and much higher than today's thick-silicon module efficiencies to attain the cost-efficiency combinations needed to achieve the longterm goals of the Five-Year Research Plan. The conclusion remains that if researchers continue to improve the efficiency and stability of large-area thin films, there is every indication that these technologies will generate electricity that is economically competitive with that from conventional generating systems in the late 1990 s.

\section{RECENT RESEARCH ACHIEVEMENTS AND NEAR-TERM THRUSTS}

Several significant PV developments have recently occurred as a result of SERI-sponsored research efforts. A highlight of the FY 1983 amorphous silicon effort was the achievement of nearly $5 \%$ ef ficiencies with submodule areas greater than $100 \mathrm{~cm}^{2}$. Beginning in 1977 , much of RCA's R\&D efforts in amorphous silicon had been spon- sored by DOE (ERDA) and SERI; Solarex Corporation recently acquired the RCA a-Si technology and key staff to further develop and commercialize the technology. Research progress has been significant enough for polycrystalline compound semiconductors that a joint venture was formed in FY 1983 to develop thin-film CuInSe ${ }_{2}$ solar cells for commercial markets. Under contract to SERI, Boeing - a partner in the venture-improved $\mathrm{CuInSe}_{2}$ cell efficiency to 11\%. A highlight of the crystalline multijunction research was the achievement of $21.5 \%$ efficiency under concentration ratios of 170 to 380 for a GaInAs cell fabricated by Varian Associates. These cells, having a 1.15-eV band gap, could be used as the bottom cell of a very high efficiency multijunction structure, or they could be used as single-junction cells in advanced concentrator modules.

Looking now at recent $R \& D$ efforts to generate new research results, SERI issued a public solicitation for innovative concepts to identify new photovoltaic materials, device configurations, and concepts for subsequent preliminary research and development. Another recent SERI R\&D thrust was the initiation in 1983 of multimillion dollar government/industry funding partnerships supporting multidisciplinary industrial teams to develop single-junction and multijunction amorphous silicon technologies. The resulting subcontracts are phased over three-year periods and are directed toward developing higher efficiency, stable, amorphous silicon solar cells.

A recent compilation of SERI and SERIsubcontracted research achievements for federal FY 1983 includes a list of scientific articles published by SERIsupported researchers (14). These publications, appearing in scientific journals or conference proceedings, continue to be the main outlet for SERI-supported research achievements. An earlier, detailed list of SERI-supported work showed that, in addition to the highly regarded publications in scientific journals and technical conferences, many PV lectures are being given throughout the United States and around the world, many master of science and doctoral theses are being written, and many patents being granted and assigned either to DOE or, as a result of a subcontractual agreement with DOE, to the private subcontractor (15). At the current photovoltaics specialists ${ }^{\prime}$ conference, SERI researchers are describing research achievements in nineteen presentations; five of these describe SERIs subcontracted R\&D programs in amorphous silicon solar cells, polycrystalline thin films, high-efficiency concepts, crystalline silicon solar cells, and photoelectrochemical cells. SERI's subcontracted researchers are giving many more detailed presentations at this conference in these research areas. Descriptions of subcontracted $R \& D$, as well as the resulting research publications, appear in DOE's recent program summary for FY 1983 (16).

These research achievements, which are best described in the technical literature in which they first appear, have demonstrated incessant increases in efficiency and stability. They are but a prologue to SERTs future work. Among the near-term technical targets of the DOE Five-Year Research Plan are 15\% efficient polycrystalline thin-film cells for areas of $100 \mathrm{~cm}^{2}$ by the year $1987,8 \%$ efficient amorphous silicon cells over $1000 \mathrm{~cm}^{2}$ in area by $1986,18 \%$ efficient amorphous thin-film multijunction cells by 1988 , and $35 \%$ efficient multijunction cells for concentrators by 1988 (1). These technical goals 
entail risks-risks that are not easily assumed by the private sector alone because of the significant long-term investment in scientific equipment and scientific personnel that they entail. Industry participation in SERIS R\&D efforts is considered vital, however, so that industry will be prepared to adopt, adapt, and develop successful research results to achieve the long-term module costefficiency goals of the Five-Year Research Plan.

\section{CONCLUSION}

The Five-Year Research Plan of the National Photovoltaics Program describes cost and efficiency goals for photovoltaic systems that will establish photovoltaics as a viable energy supply option for U.S. electric utilities in the late 1990s. Thin-film photovoltaic technologies have much potential for ultimately achieving the long-term cost goals because of cost advantages related to their low mass and energy content requirements. SERI's research achievements and near-term thrusts, especially in amorphous silicon, are directed toward developing a technology base consisting of research results on high-efficiency, stable solar cells. Using this technology base, the final achievement and demonstration of combined goals for module efficiency and module cost will be the primary responsibility of industry.

\section{ACKNOWLEDGMENT}

This work was supported by the U.S. Department of Energy under Contract No. DE-AC02-83CH 10093.

\section{REFERENCES}

1. U.S. Department of Energy, Office of Solar Electric Technologies, Photovoltaic Energy Division, "FiveYear Research Plan, 1984-1988, Photovoltaics: Electricity from Sunlight," May 1983.

2. R. W. Taylor, "Utility Requirements for Photovoltaic Power," Proceedings of the Third Symposium on Materials and New Processing Technologies for Photovoltaics, The Electrochemical Society, Inc., Vol. 82-8, P. 59, 1982.

3. R. W. Taylor, "Photovoltaic Systems Assessment: An Integrated Perspective," EPRI AP-3176-SR, Electric Power Research Institute, September 1983.

4. M. K. Armstrong-Russell, W. Freedman, and E. E. Spitler, "Photovoltaic Applications and Economics," Proceedings of SPIE, Vol. 407, p. 132, April 1983.
5. Solar Energy Research Institute and the Jet Propulsion Laboratory, "Photovoltaic Energy Systems, Program Summary," DOE/CE-0333, U.S. Department of Energy, pp. 1-4, January 1982.

6. J. Stone, "The Limits of Photovoltaic Conversion Efficiency-A Review," presented at the 1983 Annual Meeting of the American Solar Energy Society, June 1983 (available as SERI/TP-211-1990, Solar Energy Research Institute).

7. Jet Propulsion Laboratory, "Assessment of the Technology Required to Develop Photovoltaic Power Systems for Large Scale National Energy Applications," NSF-RA-N-74-072, October 1974.

8. T. J. Coutts and R. Hill, "Resource Constraints on the Large Scale Terrestrial Exploitation of Solar Cells," Third International Conference on Future Energy Concepts, Institution of Electrical Engineers, London, p. 147, 1981 .

9. E. Costogue and R. Pellin, "Polycrystalline Silicon Material Availability and Market Pricing Outlook Study for 1980-88," DOE/JPL-1012-79, Jet Propulsion Laboratory, January 1983.

10. K. Hay, J. D. L. Harrison, R. Hill, and T. Riaz, "A Comparison of Solar Cell Production Technologies Through Their Economic Impact on Society," Fifteenth IEEE Photovoltaic Specialists Conference, p. 267, 1981.

11. R. L. Watts, W. E. Gurwell, G. H. Bloomster, S. A., Smith, T. A. Nelson, and W. W. Pawlewicz, "Some Potential Material Supply Constraints in the Deployment of Photovoltaic Solar Electric Systems," Battelle PNL-2971 (see Appendix B), Battelle Pacific Northwest Laboratories, September 1978.

12. S. A. Smith, R. L. Watts, P. Martin, W. E. Gurwell, "Evaluation of Critical Materials in Five Additional Advance Design Photovoltaic Cells," PNL-370, Battelle Pacific Northwest Laboratories, February 1981.

13. R. L. Watts, "The Evaluation of Critical Materials for Five Advanced Design Photovoltaic Cells with an Assessment of Indium and Gallium," PNL-3319, Battelle Pacific Northwest Laboratories, May 1980.

14. Solar Energy Research Institute, "SERI Photovoltaics Advanced Research and Development: FY 1983 Accomplishments," SERI/PR-211-2236, April 1984.

15. Solar Energy Research Institute, "Photovoltaics Advanced Research and Development Bibliography," SERI/SP-281-1899, February 1983.

16. Solar Energy Research Institute and Jet Propulsion Laboratory, "Photovoltaic Energy Systems-Program Summary for Fiscal Year 1983," DOE/CE-0033/2, January 1984. 